\title{
Speciation and Analysis of Arsenic(III) and Arsenic(V) by Electrochemical Hydride Generation Spectrophotometric Method
}

\author{
Mohammad Hossein Arbab-Zavar, ${ }^{\dagger}$ Mahmoud Chamsaz, and Tahereh HeIDARI \\ Department of Chemistry, Faculty of Science, Ferdowsi University of Mashhad, Mashhad, Iran
}

\begin{abstract}
A simple method was developed for speciation and spectrophotometric determination of inorganic As(III) and As(V) using an electrochemical hydride generation technique. For speciation of As(III) and As(V), a graphite rod was used as cathode to reduce $\mathrm{As}(\mathrm{III})$ to $\mathrm{AsH}_{3}$, the rod was then replaced with a tin-lead alloy wire for reducing $\mathrm{As}(\mathrm{V})$ to $\mathrm{AsH}_{3}$. The spectrophotometric determination was based on the reaction of $\mathrm{AsH}_{3}$ with silver diethyldithiocarbamate to give an absorbing complex at $510 \mathrm{~nm}$. Under the optimized conditions, the calibration curves were linear over the ranges of $0.1-5 \mu \mathrm{g} \mathrm{ml}^{-1}$ for As(III) and $0.5-4.0 \mu \mathrm{g} \mathrm{ml}^{-1}$ for As(V). The concentration detection limits of 0.02 and $0.06 \mu \mathrm{g} \mathrm{ml}^{-1}$ were achieved for $\mathrm{As}(\mathrm{III})$ and $\mathrm{As}(\mathrm{V})$, respectively. The relative standard deviations for five replicate speciation and determination of $3.0 \mu \mathrm{g} \mathrm{ml}{ }^{-1} \mathrm{As}(\mathrm{III})$ and $\mathrm{As}(\mathrm{V})$ were 0.8 and $7.2 \%$, respectively. The accuracy and recovery of the method were evaluated by analyzing tap water spiked with $\mathrm{As}(\mathrm{III})$ and $\mathrm{As}(\mathrm{V})$.
\end{abstract}

(Received April 3, 2009; Accepted November 10, 2009; Published January 10, 2010)

\section{Introduction}

Living organisms are exposed to toxic arsenic (As) species primarily from food and water. Exposure to arsenic can cause a variety of adverse health effects, including dermal changes, and respiratory, cardiovascular, gastrointestinal, genotoxic, and mutagenic effects. ${ }^{1}$

Arsenic occurs in the natural environment in several chemical forms. $^{2}$ The mobility and toxicity of arsenic are determined by its oxidation states; ${ }^{3}$ thus, As(III) is reported to be $25-60$ fold more toxic than $\mathrm{As}(\mathrm{V}){ }^{4}$ It is therefore necessary to determine different species of arsenic in a real sample in order to know the toxicological and environmental impact of the arsenic present. Highly efficient separation techniques such as high performance liquid electrochemical techniques ${ }^{5,6}$ are often used for speciation of arsenic species.

These procedures are time consuming and require high instrumental investments and specially trained operators. Different methods ${ }^{7-9}$ have been published for inorganic arsenic speciation by chemical hydride generation $(\mathrm{CHG})$ (coupled with AAS) using different reducing agents for pre-reduction of $\mathrm{As}(\mathrm{V})$. However, the $\mathrm{CHG}$ techniques based on using $\mathrm{NaBH}_{4}$ have certain disadvantages. $\mathrm{NaBH}_{4}$ is a potential source of contamination, which may limit the detection power; ${ }^{10}$ it is expensive; and its aqueous solution is unstable and should, therefore, be prepared freshly each working day. ${ }^{11}$ Furthermore, this system is prone to interferences from coexisting ions. ${ }^{12-15}$

More recently, the electrochemical hydride generation (Ec-HG) has been introduced as a suitable alternative to common chemical hydride generation by $\mathrm{NaBH}_{4}\left(\mathrm{NaBH}_{4}-\mathrm{CHG}\right)$. $^{13,16-21}$ Ec-HG benefits several advantages compared to chemical methods. It alleviates the use of $\mathrm{NaBH}_{4}$, and has been shown to

$\dagger$ To whom correspondence should be addressed.

E-mail: arbab@um.ac.ir provide an equally sensitive but potentially cleaner approach to $\mathrm{CHG}$, together with the ease of operation. The most often reported construction of the electrolytic cell consists of two-half cells, the anodic and cathodic ones, usually separated by an ion exchange membrane or a porous glass frit. Several cathode materials have been proposed for Ec-HG. The most useful materials seem to be carbon in its different forms and $\mathrm{Pb}^{22}$

There are few studies on the use of Ec-HG for elemental speciation. Schaumloffel and Neidhart ${ }^{23}$ introduced an automatic pre-reduction system to determine $\mathrm{As}(\mathrm{III})$ and $\mathrm{As}(\mathrm{V})$ with electrochemical hydride generation and atomic absorption detection. Pyell et al. ${ }^{17}$ reported that, the selectivity could be changed by variation of the cathode material, opening the possibility to circumvent a pre-reduction step. $\mathrm{Li}$ et al. ${ }^{24}$ developed a method for speciation of inorganic arsenic by controlling the electrolytic currents.

The aim of this study is to develop a simple, sensitive and reliable method for direct determination of traces of $\mathrm{As}(\mathrm{III})$ and $\mathrm{As}(\mathrm{V})$ by a batch electrochemical hydride generation spectrophotometry system without pre-reduction of $\mathrm{As}(\mathrm{V})$. The speciation of inorganic arsenic using the proposed method was based on using different cathodic materials in the analysis. At first, the per activated graphite cathode was used to perform the reduction of $\mathrm{As}(\mathrm{III})$ to $\mathrm{AsH}_{3}$ and then after its completion, the graphite cathode was replaced with a tin-lead $(\mathrm{Sn} / \mathrm{Pb})$ alloy wire cathode in order to reduce $\mathrm{As}(\mathrm{V})$ to $\mathrm{AsH}_{3}$. Subsequently each species was determined by reaction of $\mathrm{AsH}_{3}$ with silver diethydithiocarbamate (SDDC) to give an absorbing complex at $510 \mathrm{~nm}$.

\section{Experimental}

\section{Reagents and chemicals}

All reagents used were analytical grade. The standard stock solution of As(III) $\left(1000 \mu \mathrm{g} \mathrm{ml}^{-1}\right)$ was prepared by dissolving 
$0.1320 \mathrm{~g}$ of $\mathrm{As}_{2} \mathrm{O}_{3}$ (Merck) in $10 \mathrm{ml}$ of $0.1 \mathrm{~mol} \mathrm{l}^{-1} \mathrm{NaOH}$ (Merck) solution, followed by neutralization with $0.2 \mathrm{~mol} \mathrm{l}^{-1}$ $\mathrm{H}_{2} \mathrm{SO}_{4}$ (Aldrich) and diluting to $100 \mathrm{ml}$ with distilled water. The As(V) standard stock solution of $1000 \mu \mathrm{g} \mathrm{ml}^{-1}$ was prepared by dissolving $0.4165 \mathrm{~g}$ of $\mathrm{Na}_{2} \mathrm{HAsO}_{4} \cdot 7 \mathrm{H}_{2} \mathrm{O}(\mathrm{BDH})$ in $0.1 \mathrm{~mol} \mathrm{l}^{-1}$ $\mathrm{HCl}$ (Merck) and diluting to $100 \mathrm{ml}$ with distilled water. Working standard solutions were prepared daily by further dilution with appropriate concentrations of $\mathrm{H}_{2} \mathrm{SO}_{4}$. The SDDC solution was prepared by dissolving $5 \mathrm{ml}$ morpholine (Fluka) in $200 \mathrm{ml}$ chloroform (Merck), followed by adding $1.000 \mathrm{~g}$ SDDC (Merck) and diluting to $250 \mathrm{ml}$ with chloroform. This solution was filtered and stored in the dark..$^{25}$ Nitrogen of high purity was used as the carrier gas (Sabalan, Iran). For interference studies, solutions $\left(1000 \mu \mathrm{g} \mathrm{ml}^{-1}\right)$ of sulfate or chloride salts were used.

\section{Apparatus}

All spectrophotometric measurements were made with an Agilent 8453 spectrophotometer equipped with a 1-cm path length glass cell. The spectrophotometer was interfaced to a personal computer furnished with the G1115A software.

The electrochemical hydride generation system was similar to that described by Arbab-Zavar and Hashemi. ${ }^{25}$ The hydride generator consists of a cathodic cell immersed in the electrolyte of the anodic cell. A porous glass frit separates the anode and the cathode, and allows electrical conduction between them. A coil of platinum wire having a surface area of $1.0 \mathrm{~cm}^{2}$ served as the anode and graphite rod $(4 \mathrm{~cm}$ long and $0.5 \mathrm{~cm}$ in diameter) or a coil of $\mathrm{Sn} / \mathrm{Pb}$ alloy wire $(\mathrm{Sn}: \mathrm{Pb} 63: 37,10 \mathrm{~cm}$ long and $1 \mathrm{~mm}$ diameter) were used as the cathode for determination of As(III) and As(V), respectively. A power supply (ADAK-302 PS, Iran) with a coupled current controller provided a constant current for electrolysis. In this system, nitrogen carrier gas passes through vanadium(II) perchlorate solution to remove oxygen impurities and then enters the cathodic compartment. Immediately after the electrochemical hydride generation, the gaseous products are swept off through the sodium hydroxide pellets to remove acid and water vapors, and then introduced into the SDDC absorber U-tube, containing $2 \mathrm{~mm}$ diameter glass beads and a lead acetate scrubber.

\section{Procedure}

One hundred milliliters of $1 \mathrm{~mol} \mathrm{l}^{-1} \mathrm{H}_{2} \mathrm{SO}_{4}$ were transferred to the anodic cell, and $10 \mathrm{ml}$ of sample or standard solution was transferred into the cathodic cell. The absorber U-tube was filled with $5 \mathrm{ml} \mathrm{SDDC}$ solution. The cathode (graphite or $\mathrm{Sn} / \mathrm{Pb}$ alloy) was then mounted and the cell was operated with a constant direct current. The $\mathrm{AsH}_{3}$ formed at the cathode was purged by a stream of $\mathrm{N}_{2}$ gas and transported into the absorber U-tube, in which $\mathrm{AsH}_{3}$ reacts with SDDC to form a colored absorbing complex at $510 \mathrm{~nm}$. After 15 or $25 \mathrm{~min}$, for As(III) or As(V) respectively, the SDDC solution was then removed, diluted to $5 \mathrm{ml}$ with chloroform and its absorbance was measured at $510 \mathrm{~nm}$. When the graphite cathode was used, pretreatment of the cathode was required. The surface of the graphite cathode was polished with fine sandpaper and was then washed successively with $0.1 \mathrm{M} \mathrm{HNO}_{3}$, acetone, ethanol (95\%) and distilled water. Finally, the electrode was anodically activated at a constant current of $2 \mathrm{~mA}$ in $0.1 \mathrm{M} \mathrm{H}_{2} \mathrm{SO}_{4}$ for $20 \mathrm{~min}$ and stored in $0.1 \mathrm{M} \mathrm{H}_{2} \mathrm{SO}_{4}$ before use. ${ }^{25}$ Also, when the $\mathrm{Sn} / \mathrm{Pb}$ alloy cathode was used, changing of the cathode was required, due to alternation of the surface structure of the cathode. Replacement of the old cathode with a new one provided a reproducible cathode surface, avoiding the necessity of conditioning the cathode surface. The new cathode surface
Table 1 Effect of cathode materials on measured absorbance of $2 \mu \mathrm{g} \mathrm{ml}^{-1} \mathrm{As}(\mathrm{III})$ and $2 \mu \mathrm{g} \mathrm{ml}^{-1} \mathrm{As}(\mathrm{V})$

\begin{tabular}{llc}
\hline & \multicolumn{2}{c}{ Analyte } \\
\cline { 2 - 3 } Cathode material & As(III) & As(V) \\
\hline $\mathrm{Pt}$ & $0.08^{\mathrm{a}}$ & 0.02 \\
$\mathrm{~Pb}$ & 0.35 & 0.15 \\
$\mathrm{Sn} / \mathrm{Pb}$ & 0.38 & 0.24 \\
Graphite & 0.39 & 0.02 \\
Activated graphite & 0.54 & 0.01 \\
\hline
\end{tabular}

a. Measured absorbance value (mean of three replicates).

Conditions: catholyte, $1 \mathrm{~mol} \mathrm{l}^{-1} \mathrm{HCl}$; electrolytic current, $100 \mathrm{~mA}$; electrolysis time, $15 \mathrm{~min}$ for $\mathrm{As}(\mathrm{III})$ and $20 \mathrm{~min}$ for $\mathrm{As}(\mathrm{V}) ; \mathrm{N}_{2}$ flow rate, $100 \mathrm{ml} \mathrm{min}^{-1}$.

area was set by adjustment of susceptible wire length. For determination of arsenic in samples containing As(III) and As(V), after $15 \mathrm{~min}$, which is needed for reduction of As(III) to $\mathrm{AsH}_{3}$ on the graphite cathode, the SDDC solution was decanted off, diluted to $5 \mathrm{ml}$ by chloroform and its absorbance was measured. The graphite cathode was then replaced with $\mathrm{Sn} / \mathrm{Pb}$ alloy cathode and the absorber U-tube was filled with $5 \mathrm{ml}$ new SDDC solution; then electrolysis procedures were carried out for $25 \mathrm{~min}$ as mentioned before. In order to indicate that the $\mathrm{AsH}_{3}$ formation process from $\mathrm{As}$ (III) on the graphite cathode was completed; the electrolysis procedures were carried out for $15 \mathrm{~min}$ on a sample containing As(III). After $15 \mathrm{~min}$ (which is the time needed for completed reduction of $\mathrm{As}(\mathrm{III})$ to $\mathrm{AsH}_{3}$ ), the graphite cathode was replaced with $\mathrm{Sn} / \mathrm{Pb}$ alloy cathode, the SDDC solution was removed and the absorber U-tube was filled with $5 \mathrm{ml}$ of new SDDC solution. Again electrolysis procedures were carried out for $10 \mathrm{~min}$. No absorbance was observed. For other runs, the anolyte was degassed for 2 min by $\mathrm{N}_{2}$ gas for removal of oxygen that is formed at the anode and the procedure was repeated.

\section{Results and Discussion}

\section{Cathode material and catholyte solution}

Electrodes must be made of a material that would not corrode or contaminate the solution under the applied potential. Since generation of $\mathrm{AsH}_{3}$, in acidic and neutral media, occurs with co-evolution of $\mathrm{H}_{2}$, a large hydrogen overvoltage is advantageous for the cathode. ${ }^{26}$ In our primary experiments, various materials such as the untreated shiny wires of $\mathrm{Pb}, \mathrm{Pt}, \mathrm{Sn} / \mathrm{Pb}$ alloy, graphite and activated graphite rod were investigated as cathodes for electro reduction of $\mathrm{As}(\mathrm{III})$ and $\mathrm{As}(\mathrm{V})$ to $\mathrm{AsH}_{3}$. Result are shown in Table 1, it should be noted that the blank values for each electrode was measured and no absorbance was observed. The best results were found with the activated graphite and $\mathrm{Sn} / \mathrm{Pb}$ alloy for $\mathrm{As}(\mathrm{III})$ and $\mathrm{As}(\mathrm{V})$, respectively. The response related to the use of the activated graphite cathode for As(V) was negligible. Under the constant conditions, the hydrogen overvoltage increases from $\mathrm{Pt}$ to $\mathrm{Sn} / \mathrm{Pb}$ in the following sequence: ${ }^{20} \mathrm{Pt}<$ graphite $<\mathrm{Pb}<\mathrm{Sn} / \mathrm{Pb}$.

Tin-lead alloy due to its very high hydrogen overpotential, is an ideal choice for generation of $\mathrm{AsH}_{3}$ from $\mathrm{As}(\mathrm{V})$.

$\mathrm{HCl}, \mathrm{HNO}_{3}$ and $\mathrm{H}_{2} \mathrm{SO}_{4}$ were examined as the catholyte. No absorbance was observed for $\mathrm{As}(\mathrm{III})$ and $\mathrm{As}(\mathrm{V})$ using $\mathrm{HNO}_{3}$ which will contribute to the role of $\mathrm{NO}_{3}{ }^{-}$as cathodic depolarizer for suppression of $\mathrm{AsH}_{3}$ from both $\mathrm{As}(\mathrm{III})$ and $\mathrm{As}(\mathrm{V})$. The 


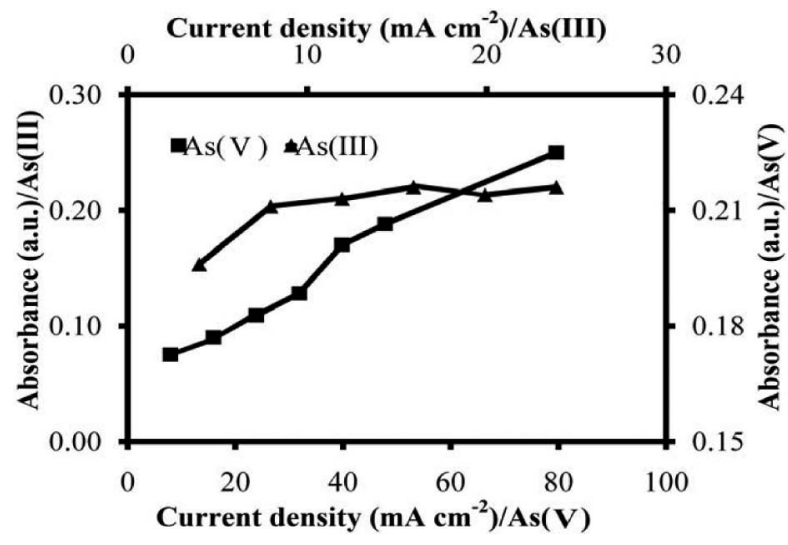

Fig. 1 Effect of applied electrolytic current density on measured absorbance of $1 \mu \mathrm{g} \mathrm{ml}^{-1} \mathrm{As}(\mathrm{III})$ and $2 \mu \mathrm{g} \mathrm{ml}^{-1} \mathrm{As}(\mathrm{V})$ : electrolysis time, $15 \mathrm{~min}$ for $\mathrm{As}(\mathrm{III})$ and $20 \mathrm{~min}$ for $\mathrm{As}(\mathrm{V}) ; \mathrm{N}_{2}$ flow rate, $200 \mathrm{ml} \mathrm{min}^{-1}$; cathode, graphite for $\mathrm{As}(\mathrm{III})$ and $\mathrm{Sn} / \mathrm{Pb}$ for $\mathrm{As}(\mathrm{V})$; $\mathrm{H}_{2} \mathrm{SO}_{4}$ concentration, $0.3 \mathrm{~mol} \mathrm{l}^{-1}$ for $\mathrm{As}(\mathrm{III})$ and $0.7 \mathrm{~mol} \mathrm{l}^{-1}$ for $\mathrm{As}(\mathrm{V})$.

suppressing effect of $\mathrm{HNO}_{3}$ on the $\mathrm{NaBH}_{4}-\mathrm{CHG}$ process is also well known. ${ }^{27}$ The comparison of measured absorbance due to $\mathrm{AsH}_{3}$ from $\mathrm{As}(\mathrm{III})$ and $\mathrm{As}(\mathrm{V})$ at the graphite and $\mathrm{Sn} / \mathrm{Pb}$ alloy cathode, respectively, showed that there was no significant difference between $\mathrm{HCl}$ and $\mathrm{H}_{2} \mathrm{SO}_{4}$ as the catholyte for the reduction of $\mathrm{As}(\mathrm{III})$. However, $\mathrm{H}_{2} \mathrm{SO}_{4}$ seemed to be a superior electrolyte for generation of $\mathrm{AsH}_{3}$ from $\mathrm{As}(\mathrm{V})$ solution and was chosen as the catholyte in this study.

\section{Concentration of the catholyte}

The effects of $\mathrm{H}_{2} \mathrm{SO}_{4}$ concentration of catholyte on $\mathrm{AsH}_{3}$ production from $\mathrm{As}(\mathrm{III})$ and $\mathrm{As}(\mathrm{V})$ by measuring the absorbance of complex related to $\mathrm{As}(\mathrm{III})$ and $\mathrm{As}(\mathrm{V})$ were investigated in the range of $0.05-1.5 \mathrm{~mol} \mathrm{l}^{-1}$. The measured absorbance increases when sulfuric acid concentration increased up to 0.3 and $0.7 \mathrm{~mol} \mathrm{l}^{-1}$ for As(III) and As(V), respectively, and then leveled off with further increase in acidity. The optimum concentration of catholyte was selected to be $1.0 \mathrm{~mol} \mathrm{l}^{-1} \mathrm{H}_{2} \mathrm{SO}_{4}$ for simultaneous generation of $\mathrm{AsH}_{3}$ from $\mathrm{As}(\mathrm{III})$ and $\mathrm{As}(\mathrm{V})$.

\section{Carrier gas flow rate}

The carrier gas, together with the excess of hydrogen produced during the electrochemical reduction, aids in separation of the volatile compound from the liquid phase and transports it via the gas-liquid separator into the SDDC absorption cell. The absorbance shows an increase with increasing the carrier gas flow rate up to $200 \mathrm{ml} \mathrm{min}^{-1}$, after which the absorbance decreases with further increase of the flow rate. At higher flow-rates, the decrease in the measured absorbance may be due to the decrease of the efficiency of the complex formation between $\mathrm{AsH}_{3}$ and SDDC, and also to the significant increase of pressure, which caused some leakage. Therefore, a $\mathrm{N}_{2}$ flow rate of $200 \mathrm{ml} \mathrm{min}^{-1}$ was selected as the optimal rate for further experiments.

\section{Electrolysis current density and electrolysis time}

The effects of the electrolysis current density on $\mathrm{AsH}_{3}$ production from $\mathrm{As}(\mathrm{III})$ and $\mathrm{As}(\mathrm{V})$ were investigated. The obtained results are shown in Fig. 1. The measured absorbance due to As(III) remained constant at the range of $4-24 \mathrm{~mA} \mathrm{~cm}^{-2}$, but the measured absorbance of $\mathrm{As}(\mathrm{V})$ increased linearly with current density up to $80 \mathrm{~mA} \mathrm{~cm}^{-2}$. The use of higher current
Table 2 The optimized experimental conditions for determination of $\mathrm{As}(\mathrm{III})$ and $\mathrm{As}(\mathrm{V})$

\begin{tabular}{|c|c|c|}
\hline Variable & As(III) & $\mathrm{As}(\mathrm{V})$ \\
\hline Anode & $\mathrm{Pt}^{\mathrm{a}}$ & $\mathrm{Pt}^{\mathrm{a}}$ \\
\hline Anolyte & $\mathrm{H}_{2} \mathrm{SO}_{4}{ }^{\mathrm{b}}$ & $\mathrm{H}_{2} \mathrm{SO}_{4}{ }^{\mathrm{b}}$ \\
\hline Anolyte concentration $/ \mathrm{mol} \mathrm{l}^{-1}$ & $1^{\mathrm{b}}$ & $1^{\mathrm{b}}$ \\
\hline Cathode & Activated graphite & $\mathrm{Sn} / \mathrm{Pb}$ alloy \\
\hline Catholyte & $\mathrm{H}_{2} \mathrm{SO}_{4}$ & $\mathrm{H}_{2} \mathrm{SO}_{4}$ \\
\hline Catholyte concentration/mol 1-1 & $\geq 0.3$ & $\geq 0.7$ \\
\hline Carrier gas flow rate $/ \mathrm{ml} \mathrm{min}^{-1}$ & 200 & 200 \\
\hline Current density $/ \mathrm{mA} \mathrm{cm}^{-2}$ & 24 & 80 \\
\hline Electrolysis/min & 15 & 25 \\
\hline Surface area of cathode $/ \mathrm{cm}^{2}$ & 6.3 & 3.2 \\
\hline Cell temperature $/{ }^{\circ} \mathrm{C}^{\mathrm{a}}$ & 25 & 25 \\
\hline
\end{tabular}

a. Ref. 25 .

b. Ref. 27.

Table 3 Analytical characteristics of As(III) and As(V)

\begin{tabular}{|c|c|c|}
\hline Parameter & As(III) & $\operatorname{As}(\mathrm{V})$ \\
\hline Calibration equation ${ }^{\mathrm{a}}$ & $A=0.2582 C+0.0031$ & $A=0.0965 C-0.0071$ \\
\hline$R^{2 \mathrm{~b}}$ & 0.9990 & 0.9995 \\
\hline Linear range $/ \mu \mathrm{g} \mathrm{m}^{-1}$ & $0.1-5.0$ & $0.5-4.0$ \\
\hline $\operatorname{RSD}^{\mathrm{c}}, \%$ & 0.8 & 7.2 \\
\hline $\mathrm{LOD}^{\mathrm{d} / \mu \mathrm{g} \mathrm{m} l^{-1}}$ & 0.02 & 0.06 \\
\hline
\end{tabular}

a. $A$ is absorbance and $C$ is the concentration of $\mathrm{As}(\mathrm{III})$ or $\mathrm{As}(\mathrm{V})$ in $\mu \mathrm{g} \mathrm{ml}^{-1}$.

b. Squared correlation coefficient.

c. Relative standard deviation.

d. Limit of detection.

density was restricted due to the considerable overheating of the electrolytic cell. Therefore a current density of 24 and 80 $\mathrm{mA} \mathrm{cm}{ }^{-2}$ were used for determination and speciation analysis of $\mathrm{As}(\mathrm{III})$ and $\mathrm{As}(\mathrm{V})$, respectively.

The effects of the electrolysis time were also investigated at current density of $24 \mathrm{~mA} \mathrm{~cm}^{-2}$ (for As(III)) and $80 \mathrm{~mA} \mathrm{~cm}$ (for $\mathrm{As}(\mathrm{V}))$. The results showed that electrolysis times of more than 15 min for $\mathrm{As}(\mathrm{III})$ and $25 \mathrm{~min}$ for $\mathrm{As}(\mathrm{V})$ were sufficient to obtain the maximum sensitivity.

\section{Cathode surface area}

The dependence of $\mathrm{AsH}_{3}$ from $\mathrm{As}(\mathrm{III})$ and $\mathrm{As}(\mathrm{V})$ with surface area of graphite and $\mathrm{Sn} / \mathrm{Pb}$ alloy cathode were investigated in the range of $1.6-6.3 \mathrm{~cm}^{2}$ (for graphite) and $0.6-3.2 \mathrm{~cm}^{2}$ (for $\mathrm{Sn} / \mathrm{Pb}$ alloy). The maximum sensitivity was observed at $6.3 \mathrm{~cm}^{2}$ (whole length of rod) of graphite cathode and in the range of $2.4-3.2 \mathrm{~cm}^{2}$ for $\mathrm{Sn} / \mathrm{Pb}$ alloy cathode.

\section{Analytical figures of merit}

Analytical figures of merit, under the optimum conditions (Table 2) were determined for electrochemical hydride generation of $\mathrm{AsH}_{3}$ from $\mathrm{As}(\mathrm{III})$ and $\mathrm{As}(\mathrm{V})$. These are summarized in Table 3. The calibration curves were linear in the ranges of $0.1-5 \mu \mathrm{g} \mathrm{ml}^{-1}$ for As(III) and of $0.5-4 \mu \mathrm{g} \mathrm{ml}^{-1}$ for $\mathrm{As}(\mathrm{V})$. Concentration detection limits based on $3 \sigma / \mathrm{m}$, where $\sigma$ is the standard deviation of five measurements of the blank and $m$ is the slope of the calibration curves, were 0.02 and $0.06 \mu \mathrm{g} \mathrm{ml}^{-1}$ for As(III) and As(V), respectively. The relative standard deviations (RSD) for five replicate measurements of $3 \mu \mathrm{g} \mathrm{ml}^{-1} \mathrm{As}(\mathrm{III})$ and $\mathrm{As}(\mathrm{V})$ were 0.8 and $7.2 \%$, respectively. 
Table 4 Effect of interferences on the determination of $3 \mu \mathrm{g} \mathrm{ml}^{-1} \mathrm{As}(\mathrm{III})$ and $3 \mu \mathrm{g} \mathrm{ml}^{-1} \mathrm{As}(\mathrm{V})$ in the presence of $1000 \mu \mathrm{g} \mathrm{ml}^{-1}$ foreign ions

\begin{tabular}{|c|c|c|c|c|c|}
\hline \multirow{2}{*}{ Species } & \multicolumn{2}{|c|}{ Recovery, \% } & \multirow{2}{*}{ Species } & \multicolumn{2}{|c|}{ Recovery, \% } \\
\hline & As(III) & $\operatorname{As}(\mathrm{V})$ & & As(III) & $\operatorname{As}(V)$ \\
\hline $\mathrm{Cl}^{-}$ & 100 & 79 & $\mathrm{Na}^{+}$ & 100 & 108 \\
\hline $\mathrm{Br}^{-}$ & 100 & 92 & $\mathrm{~K}^{+}$ & 100 & 102 \\
\hline $\mathrm{I}^{-}$ & 100 & 84 & $\mathrm{Mg}^{2+}$ & 100 & 77 \\
\hline $\mathrm{SO}_{4}{ }^{2-}$ & 100 & 99 & $\mathrm{Al}^{3+}$ & 100 & 31 \\
\hline $\mathrm{NO}^{3-}$ & 0 & 0 & $\mathrm{Fe}^{2+}$ & 99 & 50 \\
\hline $\mathrm{NO}^{2-}$ & 0 & 0 & $\mathrm{Fe}^{3+}$ & 37 & 36 \\
\hline
\end{tabular}

Table 5 Results of speciation of $\mathrm{As}(\mathrm{III})$ and $\mathrm{As}(\mathrm{V})$ in water samples by the proposed method

\begin{tabular}{|c|c|c|c|c|c|c|}
\hline \multirow{2}{*}{ Sample } & \multicolumn{2}{|c|}{$\begin{array}{l}\text { Added/ } \\
\mu \mathrm{g} \mathrm{ml}^{-1}\end{array}$} & \multicolumn{2}{|c|}{ Found $/ \mu \mathrm{g} \mathrm{ml}^{-1}$} & \multicolumn{2}{|c|}{ Recovery, \% } \\
\hline & As(III) & $\operatorname{As}(\mathrm{V})$ & As(III) & $\operatorname{As}(V)$ & As(III) & $\operatorname{As}(\mathrm{V})$ \\
\hline \multirow[t]{3}{*}{ Tap water } & 0.00 & 0.00 & $\mathrm{ND}^{\mathrm{a}}$ & ND & - & - \\
\hline & 1.00 & 1.00 & $0.99 \pm 0.01^{b}$ & $0.95 \pm 0.02$ & 99 & 95 \\
\hline & 2.50 & 2.50 & $2.55 \pm 0.00$ & $2.32 \pm 0.02$ & 102 & 93 \\
\hline
\end{tabular}

a. Not detectable.

b. Mean \pm SD (three replicates).

\section{Interferences}

The effects of co-existing various ionic species on the determination of $3 \mu \mathrm{g} \mathrm{ml}^{-1} \mathrm{As}(\mathrm{III})$ and $3 \mu \mathrm{g} \mathrm{ml}^{-1} \mathrm{As}(\mathrm{V})$ were studied in the presence of $1000 \mu \mathrm{g} \mathrm{ml}^{-1}$ of foreign ions. Results are shown in Table 4. The effects of interferences on the determination of $\mathrm{As}(\mathrm{V})$ by using $\mathrm{Sn} / \mathrm{Pb}$ alloy cathode were more serious than of As(III) by using graphite cathode, and the difference may be due to the different mechanisms for electrochemical reduction of arsenic on graphite and on $\mathrm{Sn} / \mathrm{Pb}$ alloy cathodes.

\section{Validation and application of the proposed method}

Accuracy of the proposed method was evaluated by speciation of spiked tap water samples for As(III) and As(V). Obtained results are summarized in Table 5. The good agreement between the obtained results and the known values indicates the successful applicability of the proposed method in real samples.

\section{Conclusions}

The Ec-HG system described has proven to constitute an effective approach for speciation and determination of As(III) and $\mathrm{As}(\mathrm{V})$. The speciation of inorganic arsenic can be performed using appropriate different cathodic materials without pre-reduction of $\mathrm{As}(\mathrm{V})$ in the analysis. At first, the pre-activated graphite cathode was used to perform complete reduction of
$\mathrm{As}(\mathrm{III})$ to $\mathrm{AsH}_{3}$; then, the graphite cathode was replaced with a tin-lead $(\mathrm{Sn} / \mathrm{Pb})$ alloy wire cathode in order to reduce $\mathrm{As}(\mathrm{V})$ to $\mathrm{AsH}_{3}$.

\section{References}

1. B. K. Mandal and K. T. Suzuki, Talanta, 2002, 58, 201.

2. D. Q. Hung, O. Nekrassova, and R. G. Compton, Talanta, 2004, 64, 269.

3. X. Meng, C. Jing, and G. P. Kofiatis, ACS Symp. Ser., 2003, 835,70 .

4. M. Burguera and J. L. Burguera, Talanta, 1997, 44, 1581.

5. Y. C. Sun, J. Mierzwa, and M. H. Yang, Talanta, 1997, 44, 1379.

6. H. Huang and P. K. Dasgupta, Anal. Chim. Acta, 1999, 380, 27.

7. A. J. Narsito and J. Agterdenbos, Anal. Chim. Acta, 1987, 197,315 .

8. M. Borho and P. Wilderer, J. Water, 1997, 3, 138.

9. M. E. Sigrist and H. R. Beldomenico, Spectrochim. Acta, Part B, 2004, 59, 1041.

10. R. E. Strugeon, S. N. Wille, G. I. Sproule, P. Robison, and S. S. Berman, Spectrochim. Acta, Part B, 1989, 44, 667.

11. R. Bye, Talanta, 1990, 37, 1029.

12. J. D. Winefordner and D. M. Hueber, Anal. Chim. Acta, 1995, 316, 129.

13. M. H. Arbab-Zavar and A. G. Howard, Analyst, 1981, 105, 213.

14. M. H. Arbab-Zavar and M. Hashemi, J. Sci. I. R. Iran, 1993, 4, 225

15. J. Dedina, Anal. Chem., 1982, 54, 2097.

16. F. Laborda, E. Bolea, and J. R. Castillo, J. Anal. At. Spectrom., 2000, 15, 103.

17. U. Pyell, A. Dworschak, F. Nitschke, and B. Neidhart, Fresenius J. Anal. Chem., 1999, 363, 495.

18. W. W. Ding and R. E. Sturgeon, J. Anal. At. Spectrom., 1996, 11,421 .

19. M. H. Arbab-Zavar, M. Chamsaz, A. Youssefi, and M. Aliakbari, Anal. Chim. Acta, 2005, 546, 126.

20. M. H. Arbab-Zavar, M. Chamsaz, A. Youssefi, and M. Aliakbari, Anal. Chim. Acta, 2006, 576, 215.

21. M. H. Arbab-Zavar, G. H. Rounaghi, M. Chamsaz, and M. Masrournia, Anal. Sci., 2003, 19, 473.

22. E. Denkhaus, A. Golloch, X.-M. Guo, and B. Huang, $J$. Anal. At. Spectrom., 2001, 16, 870.

23. D. Schaumloffel and B. Neidhart, Fresenius J. Anal. Chem., 1996, 354, 866.

24. X. Li, J. Jia, and Z. Wang, Anal. Chim. Acta, 2006, 560, 153.

25. M. H. Arbab-Zavar and M. Hashemi, Talanta, 2000, 52, 1007.

26. Y.-H. Lin, X.-R. Wang, D.-X. Yuan, P.-Y. Yang, B.-L. Huang, and Z.-X. Zhuang, J. Anal. At. Spectrom., 1992, 7, 287.

27. X. P. Yan and Z. M. Ni, Anal. Chim. Acta, 1994, 291, 890. 